\title{
Utilization of Secang (Caesalpinia Sappan L) Wood Extract in Optimization of Liquid Soap Formulation
}

\author{
Dwi Saryanti*, Iwan Setiawan \\ D3 Farmasi STIKES Nasional Surakarta \\ *email: dwisary_dws@yahoo.com
}

\begin{abstract}
One of the plants used in traditional medicine is secang (Caesalpinia sappan L.). Liquid soap is now widely produced because of its practical use and better appearance. The use of anionic surfactants can cause irritation and dry skin due to strong binding of skin proteins. Cocamid DEA is used as nonionic surfactant in the liquid soap formulation to reduce the irritation caused by the anionic surfactant. The determination of optimal formula of secang wood extract liquid soap used D-optimal method by using parameter of $\mathrm{pH}$ test, viscosity, density and antibacterial activity. The organoleptic, $p H$, viscosity, density, antibacterial activity, foam stability, and physical stability of optimal formula were tested by cycling test. The ratio of sodium lauryl sulfate: cocamid DEA in optimal formula of secang wood extract liquid soap was (98.95: 1.05). The optimal formula of liquid soap has pH 4.6, viscosity 51.67 dPas, density $1.06 \mathrm{~g} / \mathrm{mL}$, antibacterial activity of Staphylococcus aureus $16.2 \mathrm{~mm}$ and foam stability $96.67 \%$
\end{abstract}

Keywords: secang wood (Caesalpinia sappan (L.)), liquid soap, D-optimal

\section{INTRODUCTION}

The use of natural materials is increasing and is still a mainstay in some developing countries (Upton, 2015). The increase of herbal medicinal products circulating in the community is because natural materials are easy to obtain, the price is relatively cheaper, and the possibility of interaction and addiction is smaller than synthetic drugs (Lynch and Berry, 2007).

One of the plants used in traditional medicine is secang (Caesalpinia sappan L.).

Secang is one of plant used in herbal medication. Dried secang wood is widely used as an additive in food and beverages. The ethanol extract of the secang can be used as an antibacterial for several types of infections (Srinivasan et al., 2012), as diuretics (Pertamawati et al., 2014) and may reduce the motility of sperm mice to $65 \%$ at $25 \mathrm{mg} / 25$ $\mathrm{g}$ doses in vivo (Astuti $\mathrm{N}$ et al., 1998). Braziline is a major compound of secang wood which has several pharmacological activities as antioxidant, antibacterial, antiinflammatory, hepatoprotection, and vasorelaxation (Nilesh P. Nirmal et al., 2015). Secang wood extract has activity as antibacterial to Staphylococcus aureus bacteria with KHM value $0,125 \%$ b / v and to Shigella dysentriae bacteria with KHM value $0,25 \%$ b / v (Dianasari, 2009).

Soap is a preparation that can be used to wash clothes and cleanse the skin. Liquid soap is now widely produced because of its practical use and better appearance (Anggraini et al., 2012)

Formulations into liquid soap of secang wood ethanol extract is because of its practicality use, and its activity as a good antiseptic. The use of anionic surfactants can cause irritation and dry skin due to strong binding of skin proteins. To reduce the irritation caused by anionic surfactants, cocamid DEA is used as a nonionic surfactant in liquid soap formula (Apriyani, 2013).

The research was conducted to obtain liquid soap formula from secang wood extract which has good physical quality and antibacterial activity by using D-Optimal method. 


\section{RESEARCH METHODOLOGY Equipments and materials}

The equipment used in this research is the analytical balance (Ohaus), Rotary evaporator, capillary tube, waterbath, silica gel G 60 F 254 (Merck), UV $254 \mathrm{~nm}$ and 366 $\mathrm{nm}$ detection lamps, chamber, mortar and stamper, and pyrex degree glassware commonly used for analysis purposes.

The materials used in this study were secang obtained from Dedean, Manyaran, Wonogiri, ethanol 70\%, myristic acid, stearic acid, SLS, cocamid DEA, KOH, propylenglycol, glycerin, Na EDTA, citric acid, agar nutrient medium, and aquadest obtained from PT Bratacho

\section{Secang wood extraction}

500 grams dry powder wood is macerated with $3.75 \mathrm{~L}$ ethanol ( $5 \times 24$ hours). The obtained filtrate was collected and macerated again with $1.25 \mathrm{~L}$ ethanol $70 \%$ (1x24jam). The obtained filtrate was collected and concentrated with a rotary evaporator to obtain a spissum extract.

\section{Qualitative analysis of flavonoid compounds}

Qualitative analysis of flavonoid compounds using Thin Layer Chromatography with silica gel stationary phase and UV detectors 254 and $366 \mathrm{~nm}$. The reference standard used was quercetin. A total of $10 \mathrm{mg}$ of quercetin was diluted with $10 \mathrm{~mL}$ methanol p.a. samples of wood extract secang were weighed and dissolved in methanol p.a.

Mobile phase used is methanol: chloroform (9:1). The stationary phase used is Silica Gel F254. The reference standard solution and the sample solution were bottled in a stationary phase then incorporated into a vessel saturated with a mobile phase and covered with glass. Stain spots on the TLC plate were observed on UV lamps at wavelengths of $254 \mathrm{~nm}$ and $366 \mathrm{~nm}$. The Rf value is calculated from the stain splot obtained.

\section{Optimization of liquid soap formula}

Optimization of liquid bath soap formula used Sodium Lauril Sulfate surfactant 10 $90 \%$ w/w and Cocamid DEA 0-10\% w/w.
Total of surfactant used was $45 \%$. The optimization used D-Optimal method of 2 variables with parameters observed were $\mathrm{pH}$, viscosity, density, and antibacterial activity. The test results of the parameters are incorporated into the software to obtain the optimal formula by looking at the desirability value closest to 1 .

\section{1. pH measurement}

The $\mathrm{pH}$ test used a $\mathrm{pH}$ meter. $\mathrm{pH}$ meter was inserted into the liquid soap sample and then the $\mathrm{pH}$ observed. Before using $\mathrm{pH}$ meter, it was calibrated at standard solution $\mathrm{pH} 4$ and $\mathrm{pH} 7$.

\section{Viscosity test}

Viscosity test used Viscotester Rion VT 04-F. The sample was placed on the test chamber then the appropriate rotor was selected and the tool was run.

\section{Density test}

Density test used pycnometer. Empty piknometer was weighed. The piknometer was filled fully with aquadest and the temperature was lowered to $20^{\circ} \mathrm{C}$, if volume decreased, aquadest is added through the capillary. The temperature was raised to $25^{\circ} \mathrm{C}$ and weighed. Experiments on the sample liquid were the same as aquadest.

\section{Antibacterial activity test}

The antibacterial activity test was by the well method. Several colonies of bacteria from 24-hour growth on agar medium were taken, suspended into $0.5 \mathrm{ml}$ of liquid BHI, incubated during 5-8 hours at $37^{\circ} \mathrm{C}$. Suspension added sterile aquadest to certain turbidity in accordance with bacteria standard concentration of $10^{8} \mathrm{CFU} / \mathrm{ml}$. Cotton lid sterile was dipped into bacterial suspension and then pressed on the tube wall until the cotton was not too wet, then was applied on the surface of the media to be flat. $50 \mu \mathrm{L}$ liquid soap was dripped into the well and incubated at $37^{\circ} \mathrm{C}$ for $18-24$ hours.

\section{Manufacture of extract wood secang liquid soap}

Myristic acid, stearic acid, SLS and cocamid DEA were put into a heat-resistant container and then heated (mixture A). Propylenglycol, glycerin, Na EDTA were dissolved in $100 \mathrm{~mL}$ aquadest in different containers (mix B) and 
then $50 \%$ of it was added to the mixture A. $\mathrm{KOH}$ was dissolved with $4 \mathrm{~mL}$ of distilled water then was put in mixture $\mathrm{A}$ and was stirred until blended. The rest of the mixture $\mathrm{B}$ was added to the mixture and the diluted extract was added in aquadest and was mixed evenly. $\mathrm{pH}$ is measured and then citric acid was added.

\section{Verification of optimum formula liquid soap}

The optimum formula obtained was tested for $\mathrm{pH}$, viscosity, density and antibacterial activity. It was also tested:

\section{Organoleptic test}

Liquid soap was observed in the consistency, smell, taste and color of the formula.

\section{Foam stability test}

Foam stability test done by taking one $\mathrm{mL}$ sampling and inserting it into test tube which had been given scale, and then $5 \mathrm{~mL}$ of distilled water was added. The reaction tube was shaken strongly to form a foam and then the height of the foam formed was measured. The height of the formed foam was measured at $5,10,15,20,25$ and 30 minutes. Calculation of results used equation 2 .

Foam stability

$$
=\frac{\text { end foam height }(\mathrm{mm})}{\text { start foam height }(\mathrm{mm})} \times 100 \%
$$

\section{Data Analysis}

Determination of optimal formula by using D-optimal method, the predicted value of software and experimental results was analyzed with openstat program and standard deviation value was determined.

\section{RESULT AND DISCUSSION}

Extraction wood secang used maseration method for it was a cheap and simple method and it is suitable for compounds that are not resistant to high heating. Flavonoid is polar compound, so it used ethanol as polar solvent, in accordance with the principle of like dissolve like which is polar compounds are soluble in polar solvents and non polar compounds are soluble in non-polar solvents (Hidayati et al, 2012). The yield extract obtained was $7.12 \%$.
The results of qualitative testing of TLC showed that in secang wood extract contained flavonoid compounds. The content of flavonoid compounds was indicated by the yellow spots. The presence of flavonoid compound was indicated from the Rf value of extract 0.5 and the $\mathrm{Rf}$ value of the reference standard was 0.5 . Rf value indicates that secang wood extract contains quersetin which is a marker of flavonoid compounds (Pertiwi, et al, 2017)

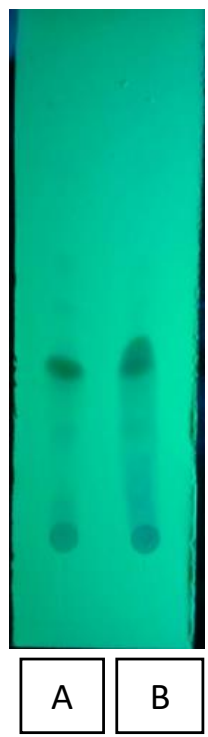

Figure 1. Qualitative test result A: reference standard B: secang wood extract

Optimization of liquid soap formula used D-optimal method. The optimized component was surfactants in liquid soap with a concentration of $45 \%$. The surfactant used was a mixture of sodium lauryl sulfate (90$100 \%)$ and cocamid DEA (0-10\%).

Characteristic of liquid soap was seen from acidity test parameter ( $\mathrm{pH})$. $\mathrm{pH}$ of liquid soap is a quality requirement of thepreparations because the soap is used directly on the skin and will cause irritation if $\mathrm{pH}$ is not close to skin $\mathrm{pH}$. According to SNI, 1996 the condition of liquid soap is 8-11. pH liquid soap tends to be alkaline due to the presence of $\mathrm{KOH}$ components as the base material used to produce saponification reactions with fat or oil or synthetic detergents having $\mathrm{pH}$ values above neutral $\mathrm{pH}$ (Irmayanti, et al, 2014). 
From the research, the $\mathrm{pH}$ ranges from 4.4 to 5.2. This is not in accordance with SNI quality requirement because the basic ingredient used in making soap is SLS, but the $\mathrm{pH}$ of liquid bath soap is still suitable for topical usage requirement, that is $4.5-6,5$. The equation obtained from the design (actual components) is:

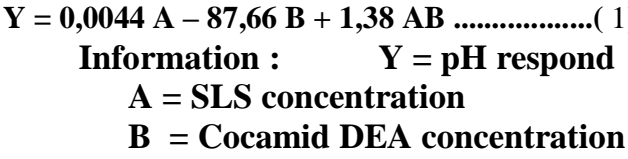

Equation (1) can give information about the influence of SLS and cocamid DEA in making liquid soap of secang wood extract. Positive effect (increasing $\mathrm{pH}$ ) is given by SLS and SLS-cocamid DEA interaction, whereas the negative effect (decreasing $\mathrm{pH}$ ) is given by cocamid DEA. The greatest effect of cocamid DEA is to decrease the $\mathrm{pH}$ becomes more acidic than the requirements of the liquid soap form. This $\mathrm{pH}$ decrease can reduce the skin irritation when liquid soap is used (Apriyani, 2013).

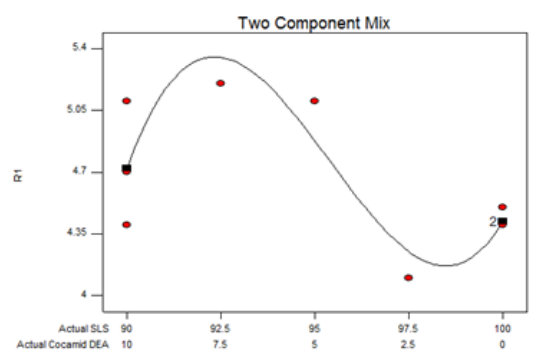

Figure 2 . Contour plot of pH test result

Figure 2 shows that the increase in SLS concentration can increase the $\mathrm{pH}$, while the upward curve shows the interaction of SLScocamid DEA that can decrease the $\mathrm{pH}$, therefore, the use of cocamid DEA can reduce the irritation of liquid soap use. The existence of this interaction is advantageous in the use of liquid soap which it will provide the comfort of the preparation when it is used.

The viscosity of the liquid soap is a description of the preparation ease when it is poured and applied. High viscosity will make the preparation difficult to pour, while low viscosity will make the preparation difficult to use. The viscosity resulting from the liquid soap extract secang wood is $15-65 \mathrm{dPas}$. The equation obtained from the design (actual components) is:

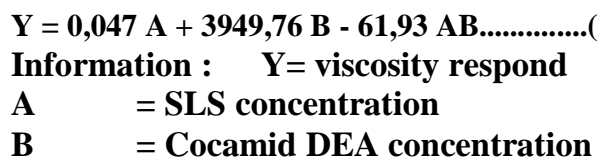

Equation (2) shows that SLS and cocamid DEA give positive effect (increasing viscosity), while SLS-cocamid DEA interaction gives negative effect (decrasing viscosity). The greatest effect of coamid DEA is the higher cocamid DEA, the higher viscosity of liquid soap.

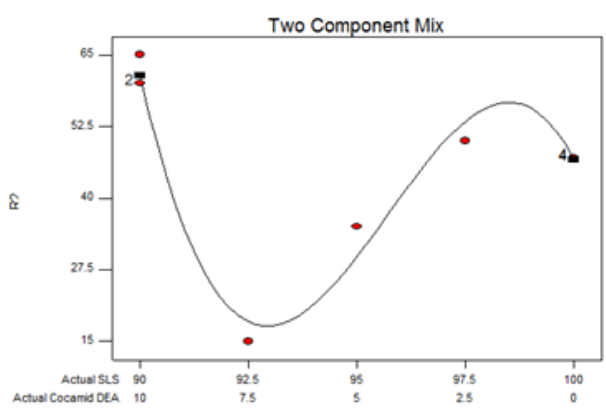

Figure 3. Contour plot of viscosity test result

Figure 3 provides information that there is an upward curve showing that SLS-cocamid DEA interaction will cause viscosity decrease. This is because cocamid DEA is more viscous than SLS that when both are combined it can decrease the viscosity.

Density is the ratio of liquid soap mass to the water mass at the same volume and temperature. Density test is to determine the effect of ingredients use in liquid soap formulations (Irmayanti, et al, 2014). Density of liquid soap formulation is $0.542-1.188$ $\mathrm{g} / \mathrm{mL}$. The density requirement of liquid soap according to SNI is about $1.010-1,100 \mathrm{~g} /$ $\mathrm{mL}$. The value of density is influenced by its constituent material and its physical properties. The density will change to be soultion when a material is dissolved into water. The density may increase by the addition of ingredients such as sugar and salt, but the density may decrease by the presence of weak acid or ethanol in the solution. The equation obtained from the design (actual components) is: 
$\mathrm{Y}=0,01 \mathrm{~A}+40,05 \mathrm{~B}-0,63 \mathrm{AB}$

Keterangan: $\quad \mathrm{Y}=$ density respond

A = SLS concentration

$\mathrm{B} \quad$ = Cocamid DEA concentration

Equation (3) shows that the positive effect (increasing the density) is given by SLS component, cocamid DEA, while the negative influence (decreasing the density) is given by the SLS-cocamid DEA interaction. The greatest effect is given by cocamid DEA; the increase of cocamid DEA concentration will increase the density of liquid soap. This is due to the consistency of cocamid DEA is so high that will increase the density.

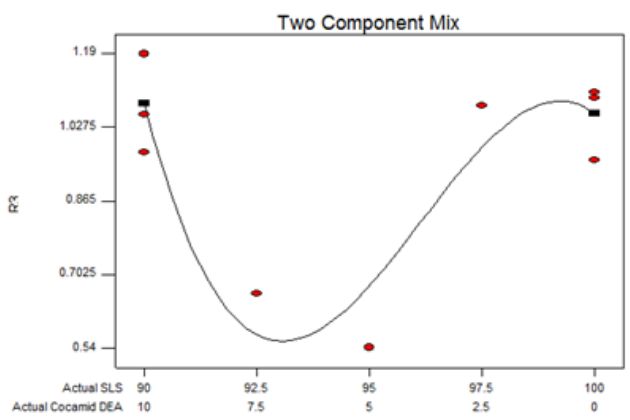

Figure 4. Contour plot of density test result

Figure 4 shows that the interaction of SLS-cocamid DEA can increase the density of liquid bath soap indicated from downward curve. The increase of density indicates that the addition of components in liquid soap can affect the density of liquid soap.

Characteristics of liquid soap seen next is the antibacterial activity of liquid soap against Staphylococcus aureus bacteria. Ability to inhibit $S$. aureus bacteria shows antibacteraial activity of liquid soap when it is used. The inhibition zone diameter of liquid soap of secang wood extract is $14.07-16.75 \mathrm{~mm}$. This indicates that the liquid soap has a weak $(10-15 \mathrm{~mm})$ to moderate $(16-20 \mathrm{~mm})$ inhibitory power (Anggraini, 2012). The equation obtained from the design (actual components) is:

$Y=0,156 A+0,024 B$

Information: $\quad \mathrm{Y}=$ antibacterial activity respond

A $=$ SLS concentration

B = Cocamid DEA concentration
Equation (4) shows the antibacterial efectiveness influenced by SLS and cocamid DEA components, and both give positive effect (increasing activity), while SLScocamid DEA interaction does not affect antibacterial activity of liquid soap. The increase of antibacterial effectiveness is more affected by SLS since the higher SLS may increase penetration of antibacteria (Yuspriadi, 2016).

Contour plot of antibacterial activity test result of liquid soap of secang wood extract can be seen in figure 5. Figure 5 indicates that there is a linear relationship. This suggests that the effectivenss of liquid soap is influenced by SLS and cocamid DEA, whereas SLS-cocamid DEA interaction has no effect on antibacterial activity.

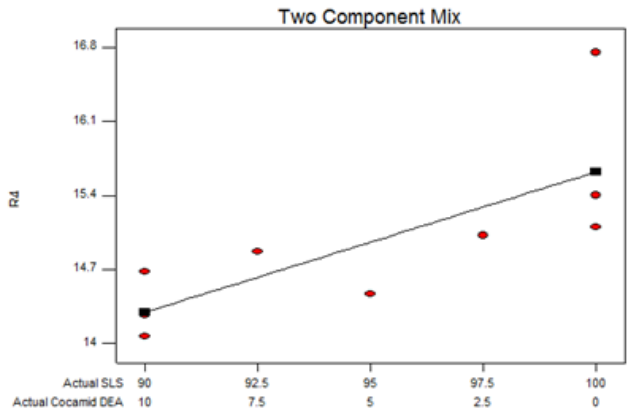

Figure 5. Contour plot of antibacterial activity test result

The formula optimization is to obtain the optimal formula of liquid soap of secang wood extract based on the response taken by looking at desirability value which is closest to 1 (Dash, 2015). Based on the results from the Expert Design software, the recommended optimal formula is the ratio of SLS: cocamid DEA (98.95: 1.05) with desirability value is 0.665 . 
Table 2. Verification result

\begin{tabular}{cccc}
\hline Parameter & Prediction & Observation & p-value \\
\hline $\mathrm{pH}$ & 4,20 & $4,6 \pm 0,23$ & 0,111 \\
Viscosity & $55,93 \mathrm{dPas}$ & $51,67 \pm 0,57 \mathrm{dPas}$ & 0,281 \\
Density & $1,08 \mathrm{~g} / \mathrm{mL}$ & $1,06 \pm 0,02 \mathrm{~g} / \mathrm{mL}$ & 0,192 \\
Antibacterial activity & $15,48 \mathrm{~mm}$ & $16,2 \pm 0,96 \mathrm{~mm}$ & 0,608 \\
\hline
\end{tabular}

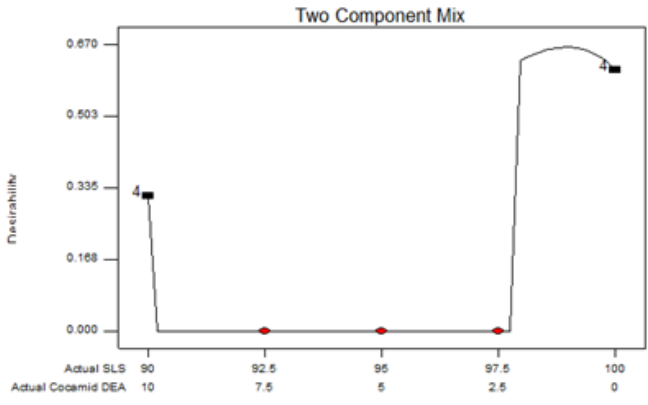

Figure 6. Contour plot of optimum formula

The organoleptic of optimal formula was tested including consistency, color, odor and taste of dosage. Organoleptic testing shows that liquid soap of secang wood extract has liquid form, transparent orange color, soaptypical-smell, taste, and slippery and soft feature. Organoleptic results indicate that liquid soap has a good physical appearance.

Verification of optimum formula can be seen on table 2 . Table 2 shows that between prediction and observation result shows there is no significant difference between prediction and observation data ( $>>0,05)$. This result means that there is a match between the prediction and the observation results that it can be said that the model used is suitable for optimization.

Foam stability testing is to see the stability of foam liquid soap. The optimum formula of liquid soap of secang wood extract has $96.67 \%$ foam stability, which means that it has good stability. This good stability of liquid soap bubble is due to the addition of cocamid DEA as the stabilizer foam. The addition of surfactant and diethanolamide can improve foam stability and make the soap softer (Apriyani, 2013).

\section{CONCLUSION}

Surfactant of sodium lauryl sulphate and cocamid DEA in comparison $(98,95: 1,05)$ are able to produce optimum liquid soap of secang wood extract. The optimum formula of liquid soap of secang wood extract using sodium lauryl sulphate and cocamid DEA have good physical quality and antibacterial activity.

\section{ACKNOWLEDGEMENTS}

Yayasan Pendidikan Farmasi Nasional funded this research.

\section{BIBLIOGRAPHY}

Anggraini, D., Rahmides, W.S., dan Malik, M., 2012. Formulasi sabun cair dari ekstrak batang nanas (Ananas comosus. L) untuk mengatasi jamur Candida albicans. Jurnal Penelitian Farmasi Indonesia, 1: 30-33.

Apriyani, D., 2013. Formulasi sediaan sabun mandi cair minyak atsiri jeruk nipis (Citrus aurantifolia) dengan cocamid DEA sebagai surfaktan. Skripsi.

Astuti N., Y.A., Dzulkarnain, B., dan Sundari, S., 1998. Penelitian Ekstrak Kayu Secang (Caesalpinia sappan L.) Terhadap Motilitas Spermatozoa Dan Laju Fertilitas Mus musculus L. Warta Tumbuhan Obat Indonesia, 4: .

Dash, R.N., Mohammed, H., Humaira, T., dan Ramesh, D., 2015. Design, optimization and evaluation of glipizide solid self-nanoemulsifying drug delivery for enhanced solubility and dissolution. Saudi Pharmaceutical Journal, 23: 528-540. 
Dianasari, N., 2009. Uji Aktivitas Antibakteri Ekstrak Etanol Kayu Secang (Caesalpinia Sappan L.) Terhadap Staphylococcus Aureus Dan Shigella Dysentriae Serta Bioautografinya. Universitas Muhammadiyah Surakarta, Surakarta.

Irmayanti, P.Y., Wijayanti, N.P.A.D., dan Arisanti, C.I.S. 2014. Optimasi Formula Sediaan Sabun Mandi Cair Dari Ekstrak Kulit Manggis (Garcinia mangostana Linn.), Jurnal Kimia, 8(2): 237-242

Lynch, N. dan Berry, D., 2007. Differences in perceived risks and benefits of herbal, over-thecounter conventional, and prescribed conventional, medicines, and the implications of this for the safe and effective use of herbal products. Complementary Therapies in Medicine, 15: 84-91.

Nilesh P. Nirmal, S. Rajput, M., G.S.V. Prasad, R., dan Ahmad, M., 2015. Brazilin from Caesalpinia sappan heartwood and its pharmacological activities: A review. Asian Pacific Journal of Tropical Biomedicine, 8: 421-430.

Pertamawati, Nuralih, dan Fahrudin, F., 2014. Ekstrak secang sebagai bahan diuretikum (percobaan terhadap tikus putih jantan galur Spraue Dawley). Al-Kauniyah Jurnal Biologi, 7: .

Pertiwi, R.D., Yari, C.E., Putra, N. F. 2017. Uji Aktivitas Antioksidan Ekstrak Etanol Limbah Kulit Buah Apel (Malus domestica Borkh) Terhadap Radikal Bebas DPPH (2,2Diphenyl -1- Picrylhydrazil). Jurnal Ilmiah Manuntung, 2, Akademi Farmasi Samarinda. Samarinda

Rostiwati, T., Heryati, Y., dan Agustarini, R., 2015. Review on research of secang (Caesalpinia sappan Linn) as source of potensial ingredient for jamu.

Sinko, P.J., 2014. Martin Farmasi Fisika Dan Ilmu Farmasetika, 5th ed. Penerbit Buku Kedokteran EGC, Jakarta.

Srinivasan, R., selvam, G.G., Karthik, S., Mathivanan, K., Baskaran, R., Karthikeyan, M., dkk., 2012. In vitro antimicrobial activity of Caesalpinia sappan L. Asian Pacific Journal of Tropical Biomedicine, 2: S136-S139.

Tiaraswara, R.A., Taufik, Y., Afrianti, L.H. 2015. Optimalisasi Formulasi Hard Candy Ekstrak Mulberry (Morus sp) Dengan Menggunakan Design Expert Metode D-optimal. Artikel. Fakultas Teknik Universitas Pasundan. Bandung.

Upton, R.R.., 2015. Chapter 3 - Traditional Herbal Medicine, Pharmacognosy, and Pharmacopoeial Standards: A Discussion at the Crossroads, dalam: Mukherjee, P.K. (Editor), Evidence-Based Validation of Herbal Medicine. Elsevier, Boston, hal. 45-85.

Yuspriadi, N.. 2016. Formulasi Gel Antijerawat Sari Jeruk Nipis dengan Na Lauril Sulfat Sebagai Peningkat Penetrasi Terhadap Aktivitas Antibakteri Pada Propioinibacterium acnes. Skripsi. Fakultas Farmasi Universitas Katolik Widya Mandala. Surabaya. 